\title{
Building Entrepreneurship in Performing Arts Industry through the Incubation Model
}

\author{
Juju Masunah \\ Department of Dance Education \\ Universitas Pendidikan Indonesia \\ Bandung, Indonesia \\ jmasunah@upi.edu
}

\author{
Rita Milyartini \\ Department of Music Education \\ Universitas Pendidikan Indonesia, \\ Bandung, Indonesia \\ ritamilyartini@upi.edu
}

\begin{abstract}
The purpose of this article is to explore the incubation model for performing arts communities to build entrepreneurship in the creative industry sector. The aim of the exploration of the incubation model is to search for a strategy in building the capacity for increasing the quality of performing arts production, to access the performing arts market, and to create network with stakeholders. We used project-based research method to diagnose, create the incubation model, do its implementation, and evaluate the model. This research involved 15 people with performing arts background; five experts in the fields of dance, music, performing arts, and entrepreneurship; and the researchers as its participants. The project was implemented on May 20-21, 2016 in Bandung. The incubation consisted of discussions, collaborations, and presentations of the community works. The experts discussed their knowledge and experiences regarding of building the business plan, producing contemporary performing arts, and accessing the national and international markets for performing arts and music industry. Participants collaborated to present their concept or/and their production. Fifteen participants came up with eight presentations of business plan, and the three experts with dance, music, and performing arts backgrounds criticized them in terms of the concepts and their production. According to the experts, the problem with their concept and production is that they are still in the safety zone; thus, they need to think out of the box to open their minds, to do more in-depth research, and to have the references in order to increase the quality of their works. Festivals and performances are the forms of their market. This model of incubation benefits the communities to change their world view of performing arts industry. However, this project needs to be followed by a community business plan in creating the production and distributing it in the festivals.
\end{abstract}

Keywords: The incubation model, performing arts, creative industry, entrepreneurship, festival

\section{INTRODUCTION}

In the fourth wave of economic development in the world is a creative economy orientation which is grounded from the creative industry sector. The Ministry of Tourism and Creative Economy of the Republic of Indonesia defined that the "creative industry is the type of industry which would generate output (product) from the utilization of creativity, expertise, and talent from an individual to create value-added products, employment, and an increase in the quality of life" [1]. Performing arts is one of the 15 subsectors of the creative industry in Indonesia. The other subsectors include advertisement; publishing; film, video, photography; television and radio; music; culinary; crafts; architecture; design; information technology; interactive games; and research and development.

In the context of industry, performing arts still has low contribution to the economic development of Indonesia, but the contribution to social and cultural values is high [2]. This is different from the music industry which has already existed in Indonesia for a long time and contributed to the economic values. Performing arts industry might not be part of our life; rather, it is part of ritual, social and cultural development. When the paradigm of economy orientation shifts to the business, performing arts can also contribute to the economic development of the artists, communities, and National Gross Domestic Income. Furthermore, the idea of economic values can maintain sustainable traditional performing arts because the artists and performers can survive from their professional skills. Based on this reason, we have conducted research that focuses on building entrepreneurship in the field of arts and culture. This research in particular is looking for a strategy to build entrepreneurship in the performing arts industry through the incubation model.

According to the President's Regulation Number 27 Year 2013, about Entrepreneurship Incubator Development, in part 1 , point 1 , incubation is defined as a process of nurturing, mentoring, and developing entrepreneurs conducted by the incubator institution[3]. The purpose is to support the quality of their business in order to survive in the competitive environment. There are two aspects in this incubation process such as tenants (participants) and the institution which has an important role to provide nurturing and qualifying entrepreneurship for the tenants.

In this research, the incubator institution is the Center for Woman, Arts and Culture Studies, The Research and Community Service Institution of Universitas Pendidikan Indonesia (UPI), while the tenants are the participants of the incubation project. The head of this institution in cooperation with the researchers organized the incubation project to answer these questions: (1) How do performers or producers of performing arts build their entrepreneurship?, (2) What are the strategies to increase their knowledge about the quality of performing arts production and gain access to the performing arts market? In this article, we describe the problem of the 
performing arts industry, the incubation model, and an analysis of reflections on how the incubation project impacts on participants in building their entrepreneurship.

\section{LITERATURE REVIEW}

Klerk's discussion about an entrepreneurial bricolage[4] entails a strategy to construct the behavior and performances of the creative industry actors. The bricolage concept is like a process of social capital blended with a new vision of individuals to sustain their creativity and network. The actors use their ideas, skills, vision, and attitudes to work collaboratively with others in the specific creative project. Relationship and collaboration become an important process to create short-term goals and to sustain entrepreneurship skills and performance in the field of creative industry sectors. To implement this concept, Klerk suggests the actors gain appropriate education and training.

The incubation model offered by Pauwels [5] is related to Klerk's suggestion. The purpose of the incubation model is to accelerate the business start-ups in the particular field. Therefore, the role of accelerators becomes an important component to provide training and mentoring for creative actors. The incubation model has shifted from providing physical and financial supports to facilitating actors with accelerators. This is called a new generation incubation model. In this model, the accelerator that is an organization provides education and mentoring to the creative actors during a period of time to gain the specific targets.

When the target is the performing arts industry, the accelerators should provide education or mentorship to increase the quality of their works, networking opportunity, and access to the markets. Professional identity [6] becomes an important part in the creative industry sector, because this is a tool for entrepreneurial success.

\section{RESEARCH METHODOLOGY}

This qualitative research used a project-based method. A project-based research model is one in which the research becomes an integral part of some social change projects[7]. The change focus can be an individual, an organization, a community, a region, or even a society. The important point is that the project is trying to create some differences in real people's lives, and the research exists in the service of that effort.

The focus of the project is to change the individuals in the community setting to enter the context of performing arts industry. The individuals are the tenants who were the research participants.

There is a typical social change project in this method. The project-based research begins with diagnosing some problems or issues, then the change agents develop a plan or prescription, and they implement it, and the final step is an evaluation. In this research, the change agents are the researchers who were part of the incubator institution or the accelerators.

The procedure of this research began with diagnosing the problem of the tenants in the performing arts industry. Then, we developed a plan to help tenants solve their problems through the incubation model. This model consisted of three activities, namely discussion, collaboration, and presentation. We implemented this model of incubation in two days, from May 20-21, 2016, in UPI in Bandung. We made reflection as an evaluation process. Then, we developed the second cycle based on tenants' problems in the context of performing arts industry.

This research involved the tenants, the experts, and the researchers as its participants. The tenants were individuals who participated in this incubation activity. There were 15 people with performing arts backgrounds, in which 10 people registered through filling in the application form and 5 people by invitation. The experts were three speakers and reviewers for tenants' presentation. Two researchers participated as facilitators and observers.

We used participatory observation in all activities by being moderators and facilitators. We interviewed the tenants. One of the questions was how their knowledge about production and performing arts markets before and after this incubation changed. We did documentation study using their video and portfolio and experts' notes.

We analyzed data using triangulation from observation, interview, and documentation study. We analyzed the change in tenants' knowledge about performing arts market. In addition, we analyzed experts' review to tenants' preproductions. Through this analysis we learned about the position of tenants' works and how to improve their quality in facing the demand of the market.

\section{FINDINGS AND DISCUSSION}

\section{A. Problems of the Tenants}

One of the performing arts problems in facing creative industry development is how to improve the quality of production and how to access the markets [8]. The tenants in this first cycle of incubation activity were fifteen people with various backgrounds such as music, dance, and theater. We invited them to apply online and sent them the application forms to be filled. There were ten people out of eleven who filled the application form and registered. Five people were representatives of the Department of Music Education, the Department of Dance Education, Music Students' Organization, the group of KABUMI UPI, and Institut Seni dan Budaya Indonesia (ISBI) or Indonesia Arts and Culture Institute Bandung. We also invited representatives from Department of Fine Arts Education and the English Literature Forum (ELF), but they were excluded as the research participants. We only included people with performing arts backgrounds and who were willing to be involved as research participants.

In this research, fifteen people came up with eight preproductions: six people who already had the works of performing arts and two people who only had a creative concept. In regards to access to performing arts market, $70 \%$ of the tenants almost had no access to performing arts market, while $30 \%$ of the tenants knew a little bit about the markets for performing arts. This is the problem of the tenants to enter the industry. In this project, the target of their market is not only public audiences but also festival directors and venue 
presenters who can invite the performers or their production to have tour or collaborative works in the future.

\section{B. Creating a Plan for Building Entrepreneurship}

Based on the problems, we developed the incubation model that consists of the activities such as discussion, collaboration, and presentation of the works of performing arts. The accelerators along with the researchers invited the speakers who have knowledge and experiences in the creative industry subsectors. The speakers shared and discussed their knowledge and experiences about the production process and its distribution to the markets. Later on, the tenants were encouraged to collaborate with other tenants to prepare preproductions or the works which had been created before they attended this incubation. The tenants who already had the production prepared to present their creative concept. Furthermore, the tenants presented their profile and preproduction planning. In this presentation, the Incubator Institution provided a form of service for nurturing and developing the tenants' production process. In this context, the market of their production is the festival, where audiences and buyers will be invited to come.

For nurturing the tenants, the accelerators asked three speakers to be the experts to review tenants' presentations and to nurture them until the production could be performed in the festival. The researchers acted as the facilitators for the tenants. They organized the meeting between the experts and the tenants, looked for appropriate venues, and provided the tenants with the seed money for their production. This model of incubation is a strategy for building entrepreneurship of the tenants. This should be implemented in more than one cycle to achieve the target of shifting the orientation of creating contemporary performing arts to the context of industry. However, in this article, we describe the first cycle of the project as below.

\section{Implementing the Incubation Model}

The incubation model was implemented in the first cycle on May 20-21, 2016 in Bandung. The implementation of the model began from the discussion session, and the following session was a collaboration process, then to end the session was the tenants' presentation.

\section{1) The Discussion Session}

In the discussion activity on May 20, 2016, there were five expert speakers to inspire the tenants to build their entrepreneurship. The experts have various backgrounds of the knowledge and experiences such as entrepreneurship, choreography, music industry, and production of performing arts market.

The entrepreneur of Bandung City, Marius Widyarto who is called Wiwied C59, discussed his entrepreneurial experiences in building a tagline or branding C59. He also explained that C59 came up from the name of the street Caladi (shortened into C) and number 59, where he lived and began as an entrepreneur in the t-Shirt industry. Then, he developed the tagline "ngaBandung" for various uniqueness and characteristics of Bandung like C59, Isola Heritage of UPI, Gedung Sate, etc. For thirty-six years, he worked in the t-Shirt industry which has produced billions of t-Shirts. He motivated the tenants to develop creative ideas and to be brave to start being an entrepreneur.

A choreographer and a dance educator at the Indonesia Arts Institute Surakarta, Eko Supriyanto, presented the concept of "Jailolo festival" and "Cry Jailolo" as one example of the contemporary dances in Indonesia. He stated that there were three steps to explore the production of "Cry Jailolo" such as to do in-depth research, to work with a community, and to explore the local content. According to Supriyanto, Participation Action Research (PAR) is an important part to understand the phenomenon and issue about new culture and tradition. PAR also leads the choreographer to explore a creative concept and to work with the community simultaneously. Today, the creator for the contemporary dance has to do multiple tasks, such as being a dancer, a choreographer, as well as a researcher.

Rama Thaharani is an independent producer who worked for IPAM 2013 and a director for "Seni Sini Sana" community, as well as the team work who organized the groups of Indonesia performing arts in UK National Tour 2015. She discussed access to local, national, and international performing arts markets. According to her experiences, networking is an important part for accessing the markets. Then, she gave tips for the tenants to do networking such as knowing him/herself, knowing the target, providing the materials, having an open mind, and making the move to gain network. Some kinds of materials should be prepared, like the name card, leaflet of the profile or the works, and CDs or DVDs or flash disks.

Eki Puradireja is a musician, a producer, as well as Creative Director of Asia Ocean Music in Jakarta. He discussed music industry and access to national and international markets. Puradireja explained that "the music industry or music business is the activity of a musician and an organization which works on creating, arranging, recording, producing, publishing, printing, distributing, promoting, performing, managing, and selling the music" (Presentation on May 20, 2016). He identified various music businesses from a management of artists, artists' agency, a publishing company, a studio recording, a music school, an event organizer, a promotor of music, and media (Radio, TV, Online, and Printing). Music for the business, the musician and the organization of musicians, as well as producers should make planning from preproduction, production, to post production. The producers have important roles in the music industry, because he/she will think about the quality of production, access to the budget, and access to the market.

Juju Masunah, the leader in this research project, presented a planning of the festival in Bandung which is called Bandung Performing Isola Arts Festival (BIPAF) 2016. She also provided some examples of performer's profiles from Performing Arts Market in Seoul. Furthermore, Masunah explained about the property rights of the works of performing arts.

According to Masunah, Bandung Isola Performing Arts Festival (BIPAF) is a market place to promote the works of 
traditional, popular, and contemporary performing arts. This festival will be conducted by Faculty of Arts and Design Education, Universitas Pendidikan Indonesia, in cooperation with Local Government of Bandung City. This moving festival will take place in several stages in Bandung City. Masunah stated, "For the first time, the festival will take the outdoor and indoor stages. The outdoor stage will take place in Universitas Pendidikan Indonesia where 'Isola Heritage building' will be the core background of the stage, while the indoor stage will take place in the Auditorium of Institute of Arts and Culture Bandung. BIPAF is one of the local markets for the performing arts and music production created by the participants of the incubation in Bandung. This local market hopefully can bring Indonesia performing arts to national and international festivals such as Indonesia Performing Arts Market (IPAM), Performing Arts Market in Seoul (PAMS) South Korea, and Edinburgh Fringe Festival in Scotland."

\section{2) Collaboration Session}

The idea of this collaboration session relates to types of the tenants. There were tenants who represented as an independent individual and the tenants who represented as the group or the institution. The collaboration was made among tenants to build their creative concepts for their production. Later on, after the first cycle ended, the collaboration session will simultaneously include the tenants, the experts, and the researchers. However, this article presented the collaboration among the tenants only.

In this session, the facilitators asked all participants to introduce their name and backgrounds as well as the works or the creative concepts. After introduction session, the facilitators encouraged the participants to discuss with each other and to make a collaborative group. There were six people who made collaboration. Tono Rachmat, a representative of Department of Music Education, collaborated with Jaka Falah, an independent individual who has theater background. Asep Sukmana, an independent artist who has theater background, collaborated with Hendra Permana, a representative of ISBI Bandung. Akhizatul Muhandisah, an independent individual who has dance background, followed Ayo Sunaryo from Arga Studio. Six people presented their respective concepts and works, which they had already prepared, such as Irwan Friawan from Bitara Art Show and Education Studio, Andi Aji Setiadi from KABUMI UPI, Indra Gandara, Wildan Kurnia from Shocking Rajah Performing Art, E Dikara Dhiauddin Djawas, and Addinda M. Antari a representative of English Literature Forum who has a theater group. In this incubation, we searched for people with performing arts background. Therefore, Addinda's group was excluded from the research participants, but this group was allowed to participate in the activities. Three people who could not make collaboration or presentation were representatives of students' organization in Department of Music Education. They came very late to the event.

Therefore, eight presentations of business plan were reviewed by the three experts: Eko Supriyanto, Eki Puradireja, and Rama Thaharani. Before the participants made the presentations, they discussed to revise their presentation in order to fulfill three requirements, such as a description of the group, the owner or the choreographer, and the production.
Presentation was the final activity in the incubation on May 21, 2016.

\section{3) Presentation Session}

The first presentation was by Irwan Fitriawan, a representative of Bitaria Art Show \& Education in Bandung. He presented his group's profile and the main dance production called "Blekok Dance." Blekok is the name of the wild white birds which live in the swamp areas. This bird species is hard to find because the ecosystem of Blekok birds has been slowly destroyed by ecological factors and increasingly limited space. Fitriawan did research on the Blekok birds in Kampung Rawabiyawak, Bandung, where these birds were conserved. Then, he created the dance with five female dancers inspired by the beautiful Blekok birds. The movements were very elegant, and the white color dominated the dancers' costume. The music is composed of karinding, kendang, and gamelan. This Blekok dance was presented for five minutes, which is a very short time.

The experts gave reviews that emphasized the creative concept and the production. According to Eko Supryanto, the production was like recycling the existing dance such as the Sundanese Peacock dance. Supriyanto suggested Fitriawan to deconstruct the creative concept, in which actually the birds live in jeopardy because of the bad ecosystem. Rama Thaharani agreed with Supryanto's comment, but she was interested in Fitriawan's research object, namely the Blekok bird's life. Thaharani suggested Fitriawan to re-create the result of the research to have a different version of the Blekok dance representation. However, Puradireja stated that the storyline of the research should also appear in the production. In summary, Fitriawan recommended to reinterpret the Blekok's situation and re-create the dance.

The second presentation was by Andi Aji Setiadi, a representative of KABUMI with angklung music. For thirty years, KABUMI UPI has established itself as the group which consists of students, staff, and lecturers of UPI. They have performed angklung music and traditional dances in Indonesia and abroad. In this incubation, Setiadi offered three creative concepts to participate in the festival as well as for tourism events. The concepts were for the performance, for the interactive process of how to play angklung music, and for angklung colossal performance involving 2000 players. The songs selected should have the characteristics of Bandung City, like "Halo-Halo Bandung" song.

Rama Thaharani asked this question to Setiadi: "How does it differ from Saung Angklung Udjo (SAU)?" Her question implied that KABUMI should create a different angklung presentation. Thaharani provided an example with the song "January New York" created by the Beatles, but the creator deconstructed the song so that the audiences can participate in the end. Eki Puradireja suggested KABUMI to select unique songs and re-arrange them to make a new and attractive performance package. Eko Supriyanto thought of developing a deconstruction concept for angklung music presentation that involves the dancer (Fitriawan), angklung instruments, and colossal angklung music performance. Basically, the experts suggested KABUMI to re-think the concept to differentiate themselves from SAU and deliver a new message to audiences. 
The third presentation was by Ayo Sunaryo, a representative of Arga Studio in Bandung. Sunaryo is a choreographer and dance educator who teaches choreography subject in the Department of Dance Education at UPI. For this incubation, he offered a creative concept for children's dance. The title of the pre-production is "Liwung Buruan Dance". The purpose of this production is to find a strategy to give the children an experience of traditional plays. He displayed a video of the pre-production of the children's dance.

Rama Thaharani asked, "Why don't you give the opportunity for the children who watched the performance to be involved?" She explained the references for example, the Playgroup in Melbourne, Australia, and Tetris created by a Belgium artist. Puradireja did not agree with the idea of involving the audiences because it needs a different approach for the children's dance. Then, he asked the questions, "What is the purpose of creating the children's dance? What is the message?" He also suggested Sunaryo to create its music seriously. Meanwhile, Eko Supriyanto encouraged Ayo Sunaryo to work on it because most choreographers lack focus on the children. He suggested, "Don't put a realistic play on the stage; it should work in a deconstructive way."

The fourth presentation was that by Wildan Kurnia, a choreographer and a representative of the group Shocking Rajah Performing Arts. He presented the work titled "Sinom Barangtaning Rasa", a dance theater in a one-hour performance. To create this work, Kurnia did in-depth research on the Sundanese traditional literature which is called guguritan written by Haji Hasan Mustafa. Then, Kurnia explored the literary texts up to the body movements. The experts were interested in Wildan's creative concept. Puradireja said, " "It had a very strong creative concept, and the work was already done." However, the execution of the concept was still problematic because Wildan used some kinds of inappropriate symbols. Rama Thaharani and Eko Supriyanto agreed with Puradireja's point of views. Therefore, the experts asked Kurnia to re-create the production of "Sinom Barangtaning Rasa".

The fifth presentation was by Indra Gandara, an independent choreographer in Bandung. He presented "Jagat Suwung Dance". "Jagat Suwung" means an empty world. This dance was created as a response to the bad impact of industrial technology on the ecosystem and human life in the community in Sukabumi, West Java. In Sukabumi, most rice fields have changed to the factories for industrial technology. Like the comments to Wildan Kurnia, the experts were interested in the creative concept which was very philosophical; however, the execution was still problematic. The experts suggested Gandara to re-create the work using the new symbols to get the message through to the audiences.

The sixth presentation was by E. Dikara Jawas. He presented a short piece of the music with the title "ngacapi for cello and piano No.1. Mvt I \&II". This music explored the sound of Sundanese zither (kecapi), particularly the degung scale. Dikara was interested in transforming the sound of kacapi to western instrument, like the cello or piano. According to Puradireja, the work was not clear yet, because it was presented in a very short time, and it was still in the form of concept exploration. But, it would be good if the composition involved the other pieces to meet a one-hour performance. Eko Supriyanto agreed with Puradireja that the duration of the piece should be longer. Rama suggested Dikara to have more references or watch more performances.

The seventh presentation was by Tono Rachmat. He presented the creative concept of "Music marwas Melayu." The instrument consisted of 4 marwas, 1 gambus slodang, 1 accordion, and 4 female dancers. This work consists of three parts: An introduction part, content as human life, and the end of life. A lot of Melayu stories are similar to the concept, like marshal or silat melayu, and the dance movements using marwas as property. All of the experts had no comment; they stated that they were looking forward to watching the work, because the concept looked fixed already. Rama Thaharani explained that she watched some Melayu pieces in the types of Kroncong.

The eighth presentation was by Asep Sukmana. Asep Sukmana, who has a theater background and was a postgraduate student of ISBI Bandung, presented the creative concept of "the heritage tourism of Subang" and "a monologue." To release the concept of "the heritage tourism of Subang", Sukmana would include the traditional dance from Subang which is called Ronggeng Doger Kontrak, a type of social dance between a female dancer (ronggeng) and a male dancer (bajidor). For the monologue, the actor would tell the story of a social issue in Subang. The issue is related to the shifting women's role, from the domestic to public domain. The women work for a living, while the men stay at home taking care of their children and working in a domestic domain. To do this Monologue, Sukmana would collaborate with Hendra Permana as an actor and performer. All of the experts agreed with the concept for the monologue that raises the social issue of the women in Subang. According to the experts, the message is clear: A contemporary issue about the garment industry that can shift the social structure of the family life in Subang.

According to the experts, the tenants' pre-productions that were presented above required in-depth research and rigorous literature review. The tenants also need to think out of the box to open their minds and to get out from the safety zone to increase the quality of their works. From the eight presentations, the experts have chosen three pre-productions to be funded by the research project, while the others should still be looking for sponsors. The three pre-productions are those of Indra Gandara (dance), E Dikara (music), and Asep Sukmana (theater) with indoor stage concept. However, they should pay attention to the experts' suggestions. The other three preproductions which have outdoor stage concept are those of Irwan Fitriawan (dance), Wildan Kurnia (dance theater), and angklung music of KABUMI. The two pre-productions, Tono Rachmat (music and dance) and Ayo Sunaryo (children dance), have more educational concepts.

In summary, the tenants' creative concepts and preproductions should be recreated to enter the performing arts industry. These recommendations will be followed up in the second cycle of the project. The experts will be invited on September 20, 2016, to review the re-created works. Their final product will be performed in Bandung Isola Performing Arts Festival on October 21-22, 2016. 


\section{Evaluation}

The tenants evaluated the incubation activity and they gave a reflection about their experiences. There are three positive aspects of the incubation activity, such as: (1) increasing knowledge related to performing arts market; (2) creating an understanding of the concept to produce high quality production in terms of global competitiveness; and (3) motivating them to be entrepreneurs.

$70 \%$ of the tenants who had no or limited experience about the market for performing arts did a reflection by writing anonymous notes. They provided written responses as follows: Tenant a) stated, "Before I attended this incubation, I had no knowledge about performing arts industry system. After attending these two-day activities, I knew about performing arts market." Tenant b) wrote, "After attending the incubation, I understand the cycle of performing arts market. Before attending the incubation, I was confused about the distribution of the production and access to the market." Tenant c) knew a bit about performing arts market in Indonesia, saying, "After attending the incubation, I learn more about the market for performing arts". Tenant d) wrote that "after attending the incubation, my understanding of the content and context of performing arts market has changed." Responses from $30 \%$ the tenants who already had knowledge about performing arts market show they developed the knowledge as cited their notes, “Actually, there are some aspects I wasn't aware of and it became a problem because it has made me lack the confidence to enter the market. Fortunately, the experts encouraged the tenants to expand their network. I believe that I can do this." Tips to do networking are important aspects to increase their knowledge, in which the tenant said, "I learn how the creative concept can be developed and distributed. Networking becomes new knowledge for me."

The discussion session when the speakers presented their knowledge about the creative process to produce the quality works of performing arts to enter global competitiveness opened the tenants' perspectives. After incubation, the tenants learn more about the steps to produce higher quality production. The tenant stated that "concept, process, and product are not easy to be formed without thinking about aesthetic, ethic, and logic." The other statement was that "from the incubation I learn about deconstructing local content to become a universal work. This is an important value for production process." The other tenants summarize that competitive works are unique, and the audiences can be entertained and educated at the same time.

This incubation has an effect on the changed tenants' orientation. Some tenants stated, "Incubation is an excellent activity, let's start being an entrepreneur. This activity should continue because this incubation helps improve the quality of performing arts."

\section{CONCLUSION}

The incubation model that consists of discussion, collaboration, and presentation activities is a process of nurturing the tenants to build entrepreneurship skills in the performing arts industry. Through this model, the tenants receive the knowledge and information from the experts on how to make high quality production and to access their market. This incubation model benefits the communities to change their world view of performing arts industry. This can be seen from their reflection before and after attending the incubation. They have now understood that the business plan for the production should begin with in-depth research and clear execution. Even though the incubation lasted only for two days, the tenants achieved the target of the changed orientation. They are eager to be the entrepreneurs in the performing arts industry. However, this project needs to be followed up to provide mentorships until their production can be presented in the performance or festival.

The researchers also evaluated the changes of the tenants' orientation in the first implementation cycle of the incubation model. The strong impact that inspired the tenants was the discussion session which consisted of the speakers' presentations. The tenants' weakness can be seen from the collaboration because the collaborative work requires more time for the parties involved to learn about each other's works. In the presentation session, the experts criticized the tenants' creative concepts and pre-productions, so that the tenants can create works that are appropriate to enter the industry. This form of service in the model of incubation influenced the change in the tenants' pre-production concepts. Reviews from the experts will be followed up in the next cycle of the research. The incubation model will be continued in the second cycle until October 2016.

\section{REFERENCES}

[1] Tourism and Creative Economy, Ekonomi Kreatif Kekuatan Baru Indonesia Menuju 2025 (Creative Economy: The New Power of Indonesia towards 2025). Jakarta: The Ministry of Tourism and Creative Economy, 2014.

[2] Tourism and Creative Economy, Kekuatan Baru Indonesia Menuju 20125 Rencana Aksi Jangka Menengah 2015 - 2019 (The New Power of Indonesia towards 2025: The 2015-2019 Medium Term Action Plan). Jakarta: The Ministry of Tourism and Creative Economy, 2014.

[3] S. B. Yudhoyono, "President's Regulation Number 27 of 2013 regarding Entrepreneurship Incubator Development,” 2013.

[4] S. De Klerk, "The creative industries: An entrepreneurial bricolage perspective," no. 2005, 2015.

[5] C. Pauwels, B. Clarysse, M. Wright, and J. Van Hove, "Understanding a new generation incubation model: The accelerator," Technovation, vol. 50-51, no. 2010, pp. 13-24, 2016.

[6] M. Lindgren and J. Packendorff, "Performing arts and the art of performing - On co-construction of project work and professional identities in theatres," vol. 25, pp. 354-364, 2007.

[7] R. Stoecker, Research Methods for Community Change. Thousand Oaks: Sage Publications, 2005.

[8] J. Masunah, Program dan Kegiatan Direktorat Pengembangan Seni Pertunjukan dan Industri Musik 2014 (Programs and Activities of the Directorate of Performing Arts and Music Industry Development 2014). Jakarta: Directorate of Performing Arts and Music Industry Development, 2014. 